\title{
Biochar as a Soil Amendment: Reduction in Mercury Transport from Hydraulic Mine Debris
}

\author{
Madison Brandt ${ }^{1, *}$, Deborah S. Page-Dumroese ${ }^{2} \mathbb{}$, Jackson Webster ${ }^{3}$ and Carrie Monohan ${ }^{4}$ \\ 1 Department of Geosciences, California State University Chico, Chico, CA 95929, USA \\ 2 USDA Forest Service, Rocky Mountain Research Station, Moscow, ID 83843, USA; \\ debbie.dumroese@usda.gov \\ 3 Department of Civil Engineering, California State University Chico, Chico, CA 95929, USA; \\ Jwebster13@mail.csuchico.edu \\ 4 The Sierra Fund, Nevada City, CA 95959, USA; Carrie.monohan@sierrafund.org \\ * Correspondence: Mbrandt5@mail.csuchico.edu; Tel.: +1-530-570-5537
}

Citation: Brandt, M.;

Page-Dumroese, D.S.; Webster, J.;

Monohan, C. Biochar as a Soil Amendment: Reduction in Mercury Transport from Hydraulic Mine Debris. Energies 2021, 14, 6468. https://doi.org/10.3390/en14206468

Academic Editor: Dimitrios Kalderis

Received: 31 August 2021

Accepted: 2 October 2021

Published: 9 October 2021

Publisher's Note: MDPI stays neutral with regard to jurisdictional claims in published maps and institutional affiliations.

Copyright: (c) 2021 by the authors. Licensee MDPI, Basel, Switzerland. This article is an open access article distributed under the terms and conditions of the Creative Commons Attribution (CC BY) license (https:/ / creativecommons.org/licenses/by/ $4.0 /)$.

\begin{abstract}
Mercury mining and its use in gold mine operations left a legacy of contamination in northern California. Contaminated sediments and water continue to affect local and downstream ecosystems. To assess the efficacy of biochar-amended soils on decreasing $\mathrm{Hg}$ transport, biochar was used to amend rock and sediment columns and mesocosms to decrease suspended sediment and associated mercury $(\mathrm{Hg})$ in storm water runoff from Sierra Nevada hydraulic mines. Mercurycontaminated storm water runoff and hydraulic mine debris were collected from two hydraulic mine sites in the Yuba River, California watershed. Mercury concentrations and turbidity were analyzed from storm water samples and hydraulic mine debris in three simulated storm runoff experiments using decomposed granite columns, sediment columns, and sediment mesocosms amended at $0 \%$, $2 \%$, or $5 \%$ biochar by weight. Columns containing hydraulic mine debris and mixed with $5 \%$ biochar had a significant $(p<0.05)$ reduction in filter-passed mercury $(\mathrm{FHg})$ in the outflow as compared to control columns. To simulate saturated hydraulic mine debris runoff, mesocosms were filled with mine sediment and saturated with deionized water to generate runoff. Five percent biochar in mesocosm trays decreased FHg significantly $(p<0.001)$, but, because of the angle of the tray, sediment also moved out of the trays. Biochar was effective at reducing FHg from hydraulic mine discharge. Biochar in laboratory columns with decomposed granite or mine sediments was more effective at removing $\mathrm{Hg}$ than mesocosms.
\end{abstract}

Keywords: remediation; mining sediments; abandoned gold mines; biochar; mercury

\section{Introduction}

Mercury $(\mathrm{Hg})$ was mined in California along many drainages of the Coast Range and was used extensively to aid in the recovery of gold in the Sierra Nevada, supplying approximately 11,793 metric tons of $\mathrm{Hg}$ to gold mines [1]. Mercury was used to increase the separation of gold from soil through sluicing during hydraulic mining operations [1]. Hydraulic mining operations used monitors or water cannons to excavate alluvial gravel deposits in the hillsides, leaving steep slopes that still have not revegetated. These hydraulic mining operations continue to have an ongoing effect on water quality, while also increasing suspended sediment loads and concentrations of heavy metals [2-5]. Hydraulic mine debris consists of the alluvium that was displaced by water cannons and which continues to discharge suspended sediment into Sierra Nevada streams and rivers after storm events. This debris is often contaminated with $\mathrm{Hg}[2,5,6]$.

Similar to the ongoing sediment movement into water bodies, $\mathrm{Hg}$ continues to be a concern downstream from historic hydraulic mines because low levels of total mercury (THg) (<50 ng/L) can be harmful to biotic life due to biomagnification and bioaccumulation in the aquatic and terrestrial food webs [7-9]. Previous studies indicate that anaerobic 
sulfur- and iron-reducing microbial communities methylate $\mathrm{Hg}$ and introduce methylmercury $(\mathrm{MeHg})$ into food webs $[7,10]$. Once methylated, $\mathrm{Hg}$ is fat soluble and remains within the tissue of the organism, where it can reach potentially toxic levels over time $[8,11]$.

Mercury contamination of soil, water, and biota creates challenges in mine remediation. Mercury-contaminated soils can be excavated/dredged and disposed of, but this can be a costly option [12]. Furthermore, dredging contaminated sediments can disperse pollutants into the aquatic environment and allow them to be transported downstream [3]. Low levels of $\mathrm{Hg}$ in soils $(<0.9 \mathrm{mg} / \mathrm{kg})$ and water $(<50 \mathrm{ng} / \mathrm{L})$ at mine sites have generally been ignored during mine clean-up activities and, because of the low concentrations, have not been identified as a contaminant of concern. However, with increased understanding of how $\mathrm{Hg}$ biomagnifies in the environment and the growing number of public health advisories for fish consumption because of legacy $\mathrm{Hg}$ contamination, new $\mathrm{Hg}$ remediation efforts are highly sought after.

One potentially effective, economical, and local remediation technique for reducing $\mathrm{Hg}$ contamination in soil and water is the use of biochar [13]. Biochar is a high-carbon substrate produced by pyrolysis of biomass in low- or no-oxygen environments. Depending on the processing method, the biochar has a range of particle sizes and active chemical binding sites, such as aromatic rings and phenolic groups, which can adsorb $\mathrm{Hg}$ from aqueous solutions and contaminated soil or sediments [12,14,15].

Woody residue feedstocks, from both hardwood and softwood trees, often result in biochar with a large surface area that has an increased sorption capacity for heavy metals, such as $\mathrm{Hg}$, due to the presence of chelating functional groups [16]. In the hydraulic mine areas of California, forests consist of mixed conifers, including ponderosa pine (Pinus ponderosa Lawson \& C. Lawson), and biochar made from ponderosa pine residues has been shown to have a greater affinity for heavy metal adsorption as compared to grass-derived biochar [17].

Biochar produced using hardwood or softwood feedstocks provides an effective method for remediating Hg-contaminated mine tailings and improving water quality [18]. In addition to contaminant remediation, one advantage of using wood-based biochar is that it can be manufactured locally [18]. This creates an opportunity to use low value and nonmerchantable woody residues to create biochar when forest stands are thinned. Harvest operations and biochar production can then decrease wildland fire risk or insect and disease outbreaks on public lands [13]. For example, to restore stand structure within the forests surrounding hydraulic mines in the Yuba River, thinning operations remove small-diameter trees and shrubs from overstocked stands, thus reducing a large wildfire risk. Much of the material thinned from forest stands has low- or no-value, and these nonmerchantable woody residues are often burned in slash piles. However, woody residues are valuable as the feedstock for biochar production.

Biochar can be an effective, environmentally friendly method to adsorb $\mathrm{Hg}$ from aqueous solutions or sediments. Consequently, our objective was to use laboratory testing to determine the most effective application rate of woody-biomass feedstock biochar in reducing $\mathrm{Hg}$ in storm water runoff. Our hypotheses were that biochar additions would (1) decrease water turbidity and the amounts of $\mathrm{THg}$ and $\mathrm{FHg}$ in leachate from columns, and (2) decrease the concentration of $\mathrm{Hg}$ associated with mine sediments in mesocosms. These laboratory studies will inform land managers on the most appropriate application methods of biochar to improve remediation of low levels of $\mathrm{Hg}$ in sediments and improve water quality.

\section{Materials and Methods}

\subsection{Site Description}

We selected two areas within the Sierra Nevada, California, USA for alluvial debris collection for use in three laboratory experiments. The sites, Malakoff Diggins and Blue Point Mine, are located on the Yuba River. In 1965, the California Departments of Parks and Recreation acquired the Malakoff Diggins mine site and created Malakoff Diggins State 
Park [19]. The park is located $41 \mathrm{~km}$ northeast of Nevada City, California, USA (Figure 1) and spans 1295 ha [19].

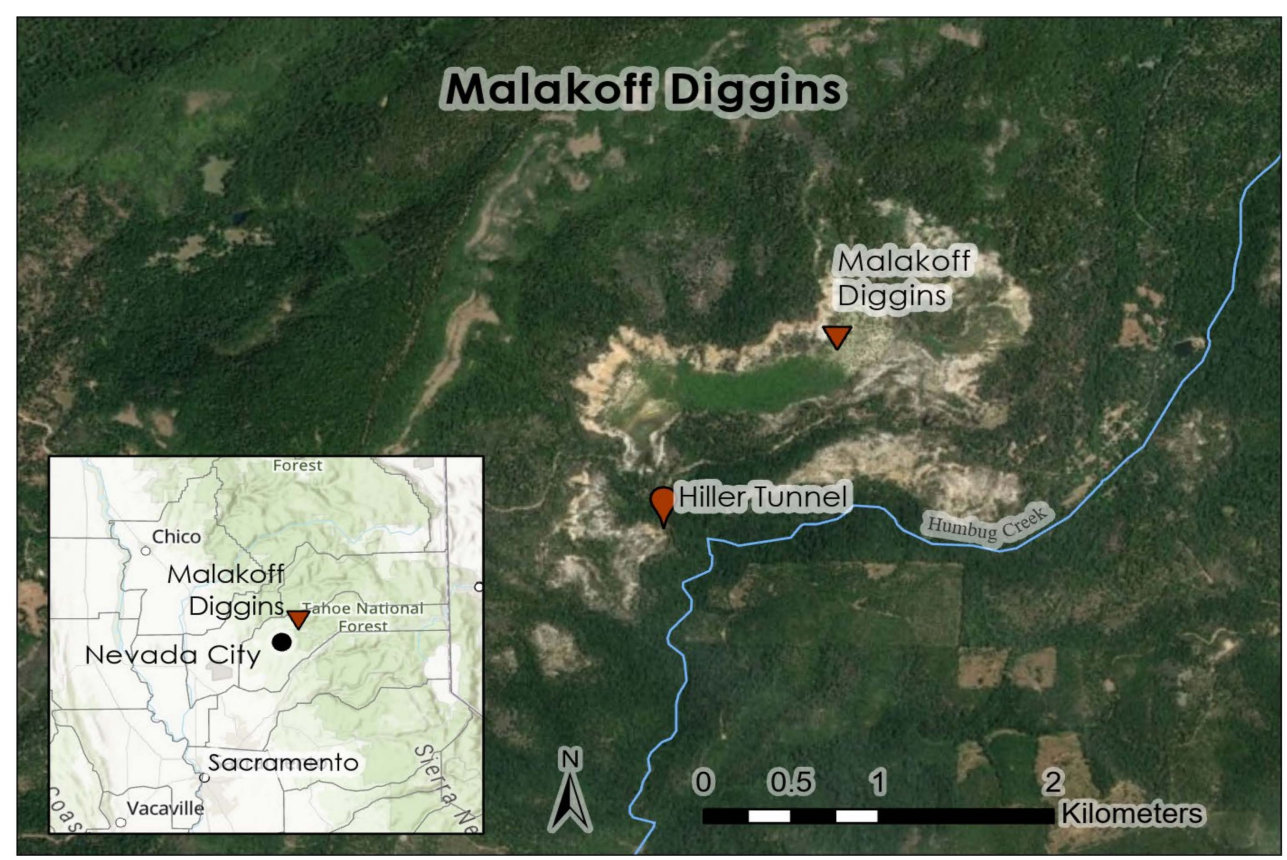

Figure 1. Map of Malakoff Diggins, including Hiller Tunnel, and the South Yuba River tributary, Humbug Creek.

Malakoff Diggins hydraulic mine pit is characterized by sparse vegetation and steep unstable walls, and is $2000 \mathrm{~m}$ in length, $1200 \mathrm{~m}$ wide, and $200 \mathrm{~m}$ deep [19]. It was once the largest historic hydraulic mine on the South Yuba River. Site geology is weathered Eocene auriferous sediments, subject to rill and gully erosion where debris flows occur [20]. The gravels are derived from weathered gold-quartz-bearing veins throughout the Sierra Nevada, and the gold-rich placer deposits were the focus of hydraulic mining efforts [1]. At the surface water drainage point from Hiller Tunnel, monitoring data indicated that $\mathrm{THg}$ concentrations range from 50 to $450 \mathrm{ng} / \mathrm{L}$ [4]. Malakoff Diggins and the Hiller Tunnel were the sources for the storm water collection used in Experiment 1 (storm water columns).

The Blue Point Mine is located downstream from Malakoff Diggins on the Yuba River near Smartsville, CA, USA (Figure 2) and is the source of sediment used in Experiment 2 (sediment columns) and Experiment 3 (mesocosms). The mine was opened in the Rose Bar mining district in 1848 and the property spans 210 ha, with site geology consisting of a basalt bedrock layer, overlaid by auriferous gravels [21]. Blue Point was mined similarly to Malakoff Diggins, with water cannons removing alluvial gravels from hillsides, and slurry processed in sluice boxes lined with $\mathrm{Hg}$. This mine used a drainage tunnel that opened onto cobble bars along the Yuba River [21]. Until 2002, the Blue Point Mine was used as a gravel quarry, concrete batch, and limited gold processing plant [21]. Hydraulic mine tailings are present throughout the site, but most of the material was deposited downstream of the drainage tunnel [21]. 


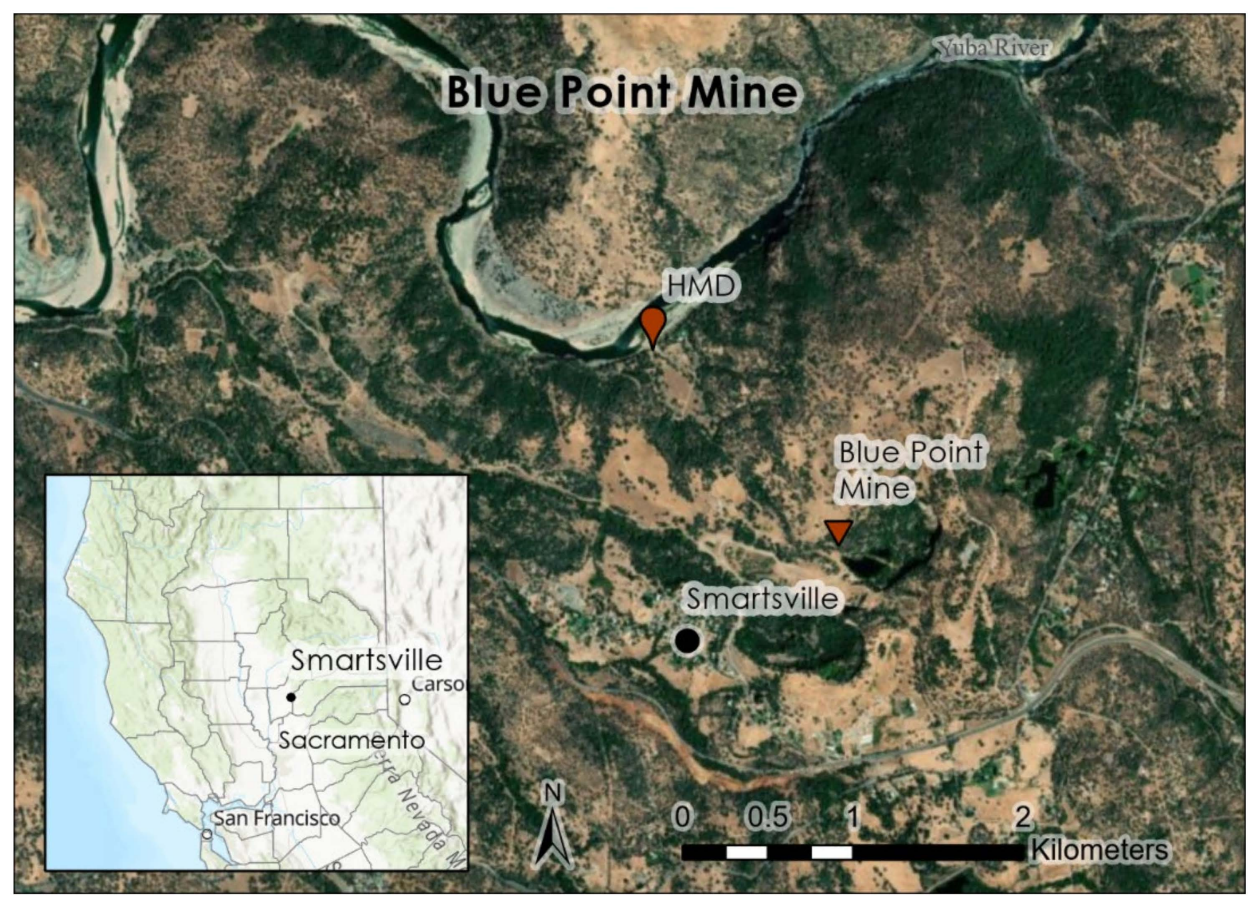

Figure 2. Map of Blue Point Mine. Located in Yuba County, CA. Hydraulic mine debris discharged from Blue Point was collected in October 2019.

\subsection{Experiment 1: Decomposed Granite-Storm Water Columns \\ 2.2.1. Storm Water Collection}

Storm water samples were collected from Hiller Tunnel on 8 March 2019 using the EPA Method 1669 clean hands $\mathrm{Hg}$ sampling. Following a storm event, 11 one-liter samples were collected in acid washed HDPE plastic bottles. Samples were refrigerated for 90 days before testing.

\subsubsection{Decomposed Granite Column Construction and Sampling}

In the laboratory, columns were constructed from PVC pipe. Nine columns, which were $30 \mathrm{~cm}$ tall with a diameter of $5 \mathrm{~cm}$, were used. A plastic screen with $840 \mu \mathrm{m}$ openings was placed on the bottom of each column to contain the filter media. Before filling the decomposed granite (purchased from a local landscaping company) columns, the material was rinsed twice with deionized water. Decomposed granite was selected as column packing material because it would not adsorb storm water or contribute $\mathrm{Hg}$ to the effluent. Biochar was obtained from the USDA Forest Service, Rocky Mountain Research Station, Moscow, ID, USA. The biochar was made from salvage logged ponderosa pine created by Phoenix Energy in Merced, CA, USA. The material was chipped to $<2 \mathrm{~cm}$ size and pyrolyzed at $\sim 500^{\circ} \mathrm{C}$. After rinsing the decomposed granite, $100 \mathrm{~g}$ was added to the column. After filling each column with decomposed granite, we randomly selected columns to receive surface-applied biochar at rates of 0,2 , and $5 \%$ of the dry weight of the decomposed granite. Each application rate was replicated three times ( 3 replicates $\times 3$ treatments $=9$ columns). The $0 \%$ biochar treatment served as the control and was used to determine baseline turbidity and $\mathrm{Hg}$ concentrations after passing storm water through the column. Columns were suspended vertically using a ring stand and clamps (Figure 3). After column preparation, $1 \mathrm{~L}$ of storm water from the Malakoff Diggins discharge tunnel was slowly poured into each column, and was not restricted at the outflow point. The leachate was collected in acid washed $125 \mathrm{~mL}$ HDPE bottles. We determined the turbidity using the Hannah 98,703 turbidimeter in the leachate and sampled from mid-depth from within the collection beakers using a $10 \mathrm{~mL}$ pipette. The leachate was sampled at 0,4 , and $24 \mathrm{~h}$ after collection. Leachate samples were also analyzed for FHg and THg after 0 and $24 \mathrm{~h}$ of leaching (method described under Section 2.5). 


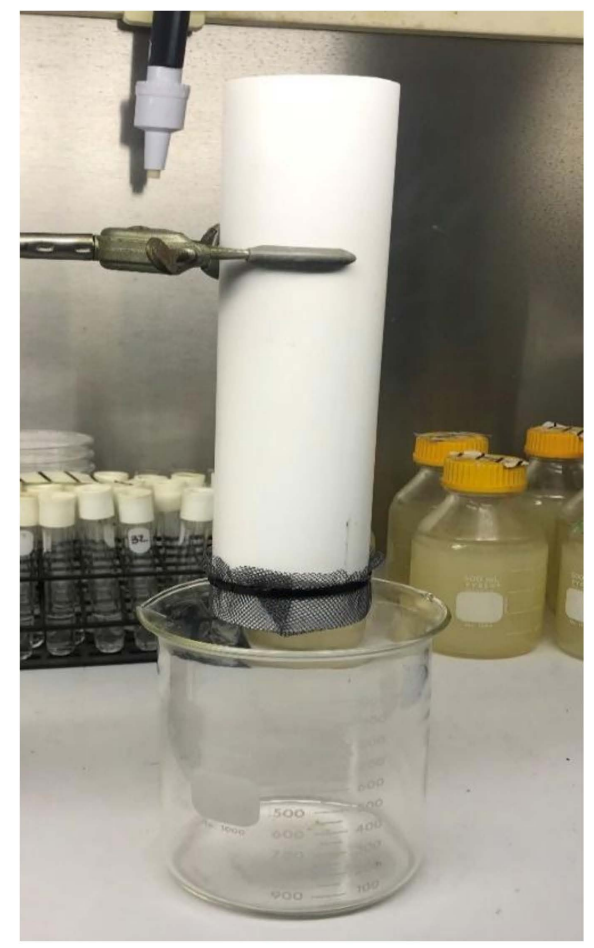

Figure 3. Column set-up is held vertically with a ring clamp and a graduated beaker is placed underneath for collection of flow through. Column contains washed decomposed granite, $0 \%, 2 \%$, or $5 \%$ biochar and $1 \mathrm{~L}$ storm water sample collected from Malakoff Diggins. Samples were passed through gravimetrically, and collected in $1 \mathrm{~L}$ graduated beaker.

\subsection{Experiment 2: Sediment Columns}

Bulk sediment samples were collected from Blue Point Hydraulic Mine on October 15, 2019 from the side wall of the creek, which has incised through hydraulic mine alluvium. Sediment was collected and placed in plastic 5-gallon buckets. In the laboratory, sand and finer-textured material $(<2 \mathrm{~mm})$, inclusive, were removed with a $3 \mathrm{~mm}$ sieve to separate them from gravel-sized material $(>4 \mathrm{~mm})$. Large organic debris, including sticks and roots, were removed. Equal mass ratios of $100 \mathrm{~g}$ of $<2 \mathrm{~mm}$ material and $100 \mathrm{~g}$ of $>4 \mathrm{~mm}$ material were recombined to create the substrate used for each sediment column experiment.

\section{Sediment Column Construction}

In this experiment, biochar and mine sediments were mixed together in a clean bucket at one of three rates of biochar: $0 \%, 2 \%$, or $5 \%$ of the dry substrate weight. Biochar (same source as Experiment 1) was mixed into the mine debris to simulate the effect of biochar tilled into the soil. In each column, the substrate consisted of $100 \mathrm{~g}$ of the $>4 \mathrm{~mm}$ gravel and $100 \mathrm{~g}$ of the $<2 \mathrm{~mm}$ fine-textured material for a total of $200 \mathrm{~g}$. Column construction was similar to that described in Experiment 1, and the unamended $(0 \%)$ columns were used as the control. Each sediment column was packed with $200 \mathrm{~g}$ of the substrate-biochar mixture and each treatment was replicated five times ( 5 replications $\times 3$ treatments $=15$ total columns). Deionized water $(800 \mathrm{~mL})$ was slowly poured through the columns, but was not restricted at the outflow point. The leachate collected in $1 \mathrm{~L}$ glass graduated bottles, which had been acid washed $(10 \% \mathrm{HNO}) 3^{-}$and rinsed with deionized water twice before use. At the end of the experiment, a $125 \mathrm{~mL}$ aliquot was extracted at mid-depth from the graduated bottle and a $10 \mathrm{~mL}$ sample was analyzed for turbidity (Hannah 98,703 turbidimeter) at three time periods: immediately after leaching, and $4 \mathrm{~h}$ and $24 \mathrm{~h}$ post-leaching. All samples extracted from the larger volume of leachate were analyzed for turbidity, $\mathrm{FHg}$, and $\mathrm{THg}$ (method described under Section 2.5). 


\subsection{Experiment 3: Sediment Mesocosms \\ Mesocosm Construction}

To determine the potential amount of $\mathrm{Hg}$ that could be redistributed in runoff, we used sediment mesocosms. Similar to Experiment 2, mine substrate was collected from the incised creek walls of the Blue Point Mine in clean 5-gallon buckets and the in situ ratios of gravel $(>4 \mathrm{~mm})$ to fine-textured $(<2 \mathrm{~mm})$ sediment were maintained. Mesocosms were built in plastic trays measuring $71 \mathrm{~cm}$ long $\times 51 \mathrm{~cm}$ wide $\times 15 \mathrm{~cm}$ deep (Figure 4) and biochar was added in 5 replications of three biochar treatment rates $(0 \%, 2 \%$, or $5 \%$; 5 replications $\times 3$ treatments $=15$ mesocosms) of the substrate dry weight and mixed in the mesocosm tray. The $0 \%$ biochar treatment was the control. The biochar source was the same as that described for Experiment 1. Once samples were mixed in the trays, they were saturated (free water drained) with deionized water to simulate runoff conditions that would occur during a rainfall event. During saturation, the mesocosm trays were angled on a slope of $10^{\circ}$ to facilitate drainage to the outlet. A total of $3 \mathrm{~L}$ of deionized water was added at a rate of $1.5 \mathrm{~L} /$ minute. Runoff and through flow were collected from a plastic valve located $3 \mathrm{~cm}$ from the mesocosm base (see Figure 4 for valve placement). The first $1 \mathrm{~L}$ of outflow was collected in $1 \mathrm{~L}$ glass bottles and was used to simulate a sample of storm water runoff, and $125 \mathrm{~mL}$ aliquots were extracted for $\mathrm{FHg}$ and $\mathrm{THg}$ analysis immediately after collection (method described in Section 2.5). In the remaining $2 \mathrm{~L}$ of collected outflow, $10 \mathrm{~mL}$ aliquots were taken at mid-depth of the catchment bottle immediately after collection $(0 \mathrm{~h})$, and $24 \mathrm{~h}$ post-collection to measure turbidity, as previously described.

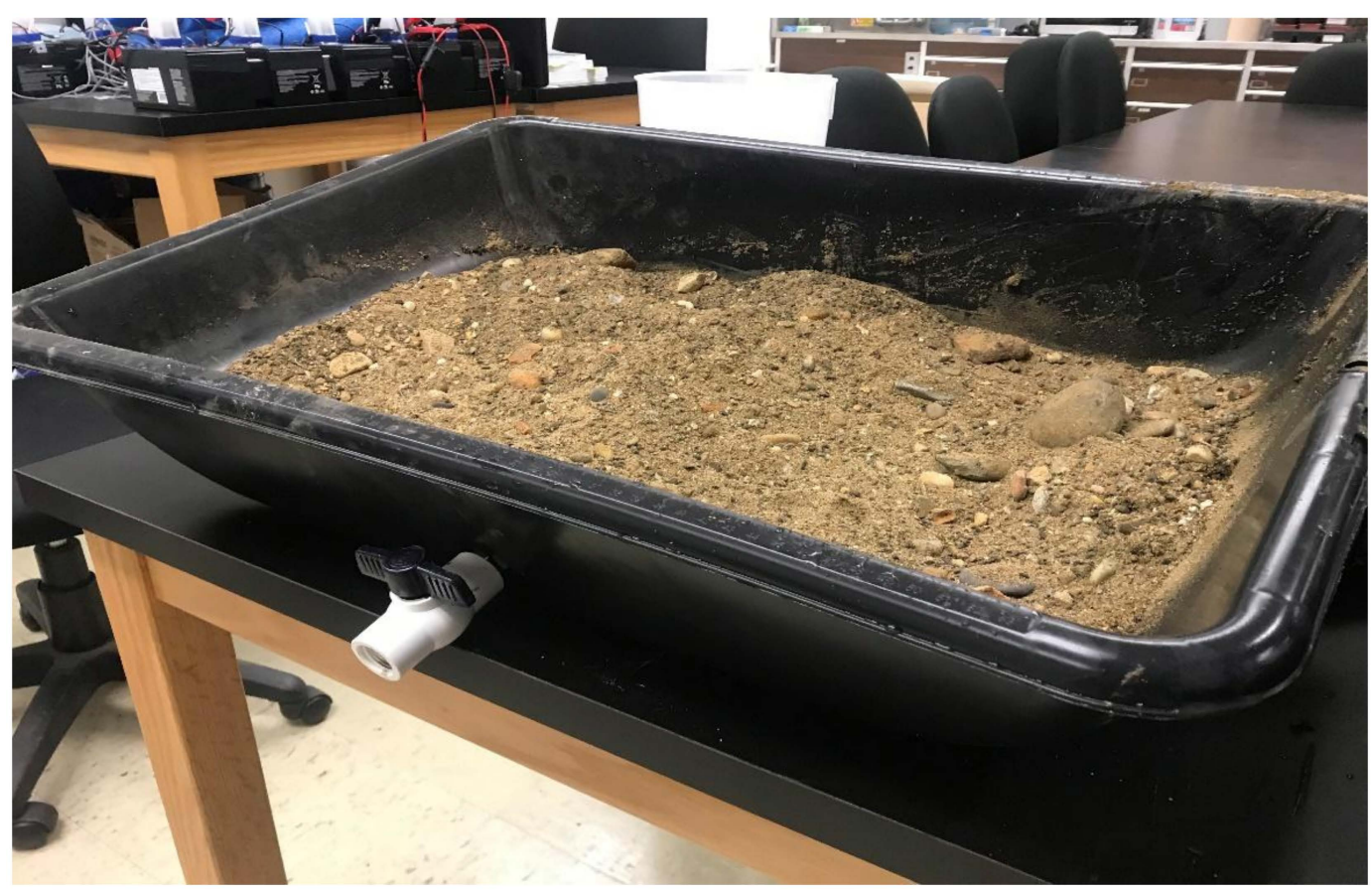

Figure 4. Sediment mesocosm tray set at $10^{\circ}$ incline, filled with $6.5 \mathrm{~L}$ of hydraulic mine debris collected from the incised creek bed at Blue Point Mine.

\subsection{Mercury and Turbidity Measurement}

Turbidity, and FHg and $\mathrm{THg}$ concentrations were determined according to the following methods. Sample volumes of $10 \mathrm{~mL}$ were collected at mid-depth following EPA Method 180.1 using pipettes. Turbidity was assessed using a Hannah 98,703 turbidimeter. The turbidimeter was calibrated according to the manual using standards at $0.1,10,100$, and 1000 NTU daily. The detection limit of EPA Method 180.1 is 0.02 NTU.

To collect samples for $\mathrm{Hg}$ analysis from outflow, sample volumes of $250 \mathrm{~mL}$ were taken at mid-depth following EPA Method 1669 using glass pipettes. Each sample was 
analyzed for total (nonfiltered) (THg) and filtered $\mathrm{Hg}$ (FHg) by Brooks Applied Labs using EPA Method 1631. Samples for filtered $\mathrm{Hg}$ analysis were passed though peristaltic pumps using $0.45 \mu \mathrm{m}$ filters to remove particulates. Particulate-bound mercury (PHg) is defined as FHg subtracted from THg present in each sample. PHg was calculated for Experiments 1, 2 , and 3 using this equation. The detection limit for EPA Method 1631 is $0.02 \mathrm{ng} / \mathrm{L}$.

\subsection{Statistical Analysis}

Data produced by Experiments 1, 2, and 3 were analyzed using R Studio (Version 3.6.2). Exploratory analysis of data from Experiment 1 was visualized using scatter plots with standard deviation. Box plots were created to visualize data from Experiment 2. Welch's two-sample $t$-tests were applied to Experiments 2 and 3 to analyze the significance between $0 \%, 2 \%$, and 5\% biochar applications $24 \mathrm{~h}$ after treatment. Data from Experiment 3 were visualized using box plots, and analyzed for significance between $0 \%, 2 \%$, and $5 \%$ biochar additions using Welch's $t$-test.

\section{Results}

\subsection{Experiment 1}

At both biochar rates the average turbidity, $\mathrm{FHg}$, and $\mathrm{THg}$ concentrations were decreased in storm water samples filtered through the decomposed granite columns at $24 \mathrm{~h}$ post-treatment as compared to the untreated control columns (Table 1). At the highest biochar rate $(5 \%)$, the standard deviation between treatment data points decreased, indicating a decreased variability in $\mathrm{FHg}, \mathrm{THg}$, and turbidity (Table 1). Decreased variability indicates a trend between the addition of biochar and the decrease in $\mathrm{THg}$ concentration in storm water samples.

Table 1. Twenty-four-hour storm water column results from Malakoff Diggins, analyzed for total ( $\mathrm{THg})$, filtered $(\mathrm{FHg})$, and particulate-bound (PHg) mercury.

\begin{tabular}{cccccc}
\hline & Biochar \% & THg (ng/L) & FHg (ng/L) & PHg (ng/L) & NTU \\
\hline & 0 & 6 & 2 & 64 & 250 \\
\hline & 0 & 20 & 3 & 17 & 130 \\
\hline Average & 0 & 32 & 3 & 29 & 170 \\
\hline & 0 & 24 & 4 & 20 & 170 \\
\hline Average & 2 & $35 \pm 18$ & $3 \pm 1$ & $32 \pm 19$ & $180 \pm 44$ \\
\hline & 2 & 23 & 2 & 22 & 160 \\
\hline & 2 & 25 & 1 & 23 & 150 \\
\hline & 5 & $27 \pm 4$ & $2 \pm 0$ & $25 \pm 4$ & $140 \pm 8$ \\
\hline Average & 21 & 1 & 20 & 160 \\
\hline & 5 & 23 & 1 & 22 & 150 \\
\hline
\end{tabular}

\subsection{Experiment 2}

Similar to the decomposed granite columns, the addition of biochar mixed into mine sediment columns decreased turbidity, THg (Figure 5), and FHg (Figure 6) as compared to the controls. Biochar additions of $2 \%$ and $5 \%$ in columns significantly decreased $\mathrm{THg}$ after $24 \mathrm{~h}$ (Figure 5, $\mathrm{n}=5, p<0.05$ ). Biochar-amended mine debris also decreased FHg after $24 \mathrm{~h}$, but is not significantly different from the control $(p>0.05)$ (Figure 6). Biochar additions of $5 \%$ by weight were not significantly different from $2 \%$ biochar by weight at reducing $\mathrm{THg}$ present $(p<0.05)$. 


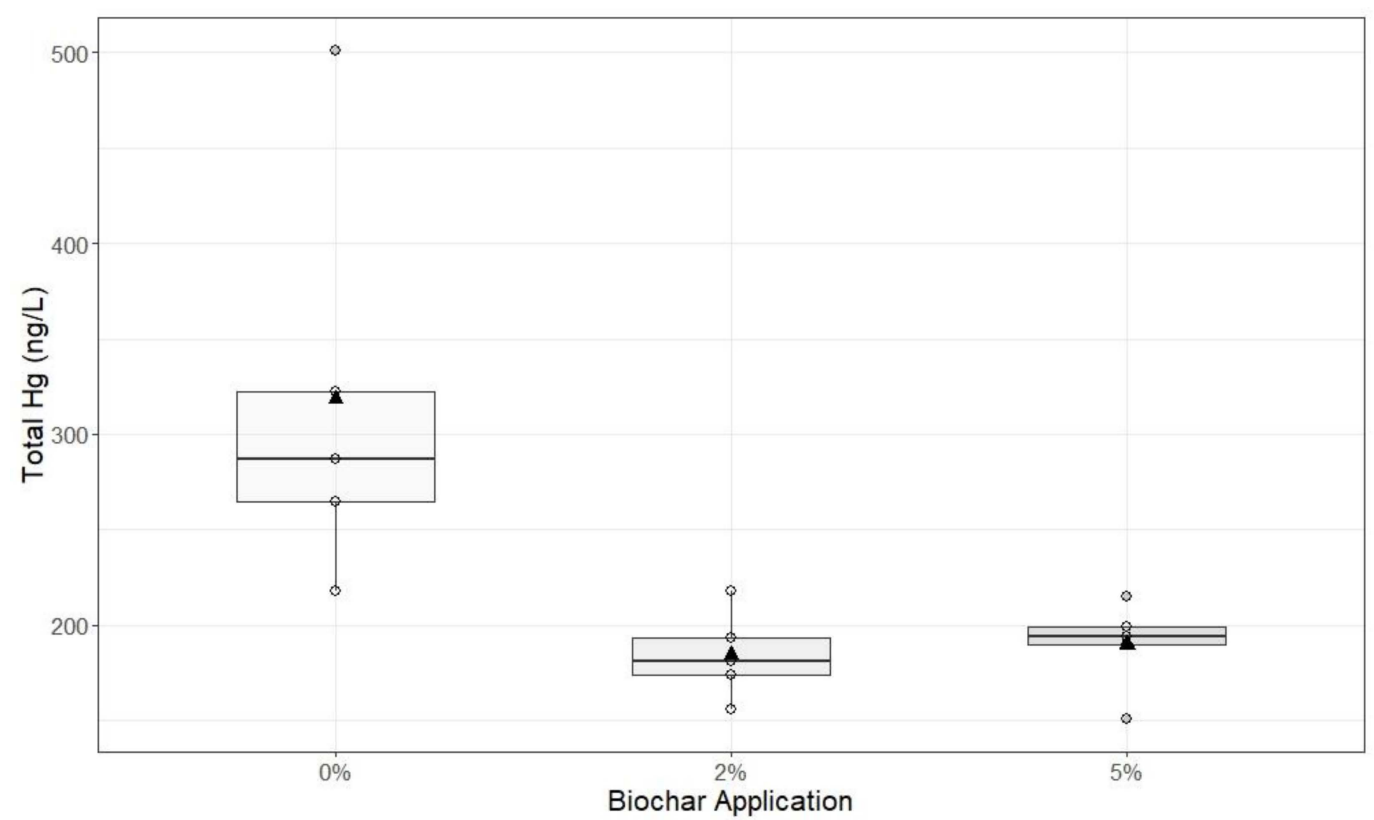

Figure 5. Total mercury in Experiment 2. Triangles indicate mean, bars show quartiles and standard deviation. Biochar additions of $2 \%$ and $5 \%$ significantly $(p<0.05)$ decreased total $\mathrm{Hg}$ in the outflow after $24 \mathrm{~h}(\mathrm{n}=5)$.

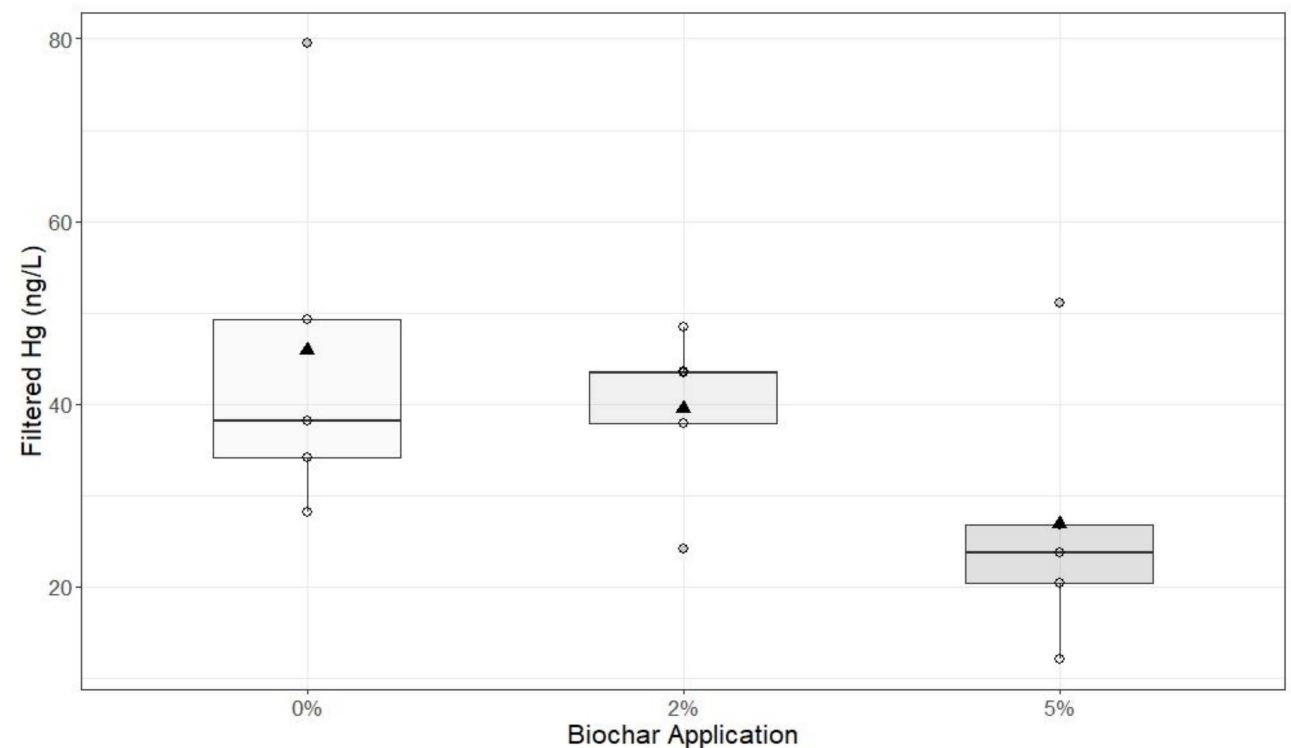

Figure 6. Filtered mercury in Experiment 2. Triangles indicate mean, bars show quartiles and standard deviation. Application of biochar at $2 \%$ and $5 \%$ by weight did not significantly reduce filtered $\mathrm{Hg}$ in the outflow after $24 \mathrm{~h}(p>0.05, \mathrm{n}=5)$.

\subsection{Experiment 3}

In the mesocosms, there was decreased $\mathrm{FHg}$, but increased $\mathrm{THg}$ along with turbidity (Table 2) in $5 \%$ treatments as compared to the $2 \%$ treatment. Biochar application of $5 \%$ by weight significantly decreased FHg (Figure 7, $\mathrm{n}=5, p=0.001$ ). We detected biochar in the runoff samples, with the amount dependent on how much was on the substrate surface and, therefore, resulting in high variability among samples collected from each mesocosm. Increasing levels of biochar resulted in greater biochar moving within the added water and resulted in increased sample turbidity. At the $5 \%$ biochar rate, we detected an increase in both $\mathrm{THg}$ and turbidity in the runoff samples, but there was a significant decrease in $\mathrm{FHg}(p=0.001)$. 
Table 2. Sediment mesocosm runoff, which was analyzed for total (THg), filtered (FHg), and particulate-bound (PHg) mercury immediately after leaching.

\begin{tabular}{|c|c|c|c|c|c|}
\hline & Biochar \% & $\begin{array}{c}\text { THg } \\
\text { (ng/L) }\end{array}$ & $\underset{\text { (ng/L) }}{\text { FHg }}$ & $\begin{array}{c}\mathrm{PHg} \\
\text { (ng/L) }\end{array}$ & NTU \\
\hline & 0 & 3530 & 44 & 3486 & 2700 \\
\hline & 0 & 3920 & 32 & 3888 & 3300 \\
\hline & 0 & 4090 & 36 & 40534 & 4000 \\
\hline & 0 & 5860 & 31 & 5829 & 4000 \\
\hline & 0 & 3450 & 35 & 3415 & 3000 \\
\hline \multirow[t]{6}{*}{ Average } & 0 & $4170 \pm 878$ & $36 \pm 5$ & $4134 \pm 881$ & $3400 \pm 525$ \\
\hline & 2 & 1920 & 15 & 1905 & 2000 \\
\hline & 2 & 4450 & 30 & 4420 & 2500 \\
\hline & 2 & 4030 & 26 & 4004 & 3900 \\
\hline & 2 & 5480 & 40 & 5440 & 5000 \\
\hline & 2 & 4740 & 42 & 4698 & 3800 \\
\hline \multirow[t]{6}{*}{ Average } & 2 & $4124 \pm 1199$ & $31 \pm 10$ & $4093 \pm 1190$ & $3440 \pm 1071$ \\
\hline & 5 & 4060 & 29 & 4031 & 1800 \\
\hline & 5 & 6810 & 18 & 6792 & 2400 \\
\hline & 5 & 7220 & 17 & 7203 & 3500 \\
\hline & 5 & 8160 & 14 & 8146 & 6000 \\
\hline & 5 & 5010 & 14 & 4996 & 3500 \\
\hline Average & 5 & $6252 \pm 1499$ & $18 \pm 6$ & $6234 \pm 1503$ & $3440 \pm 1438$ \\
\hline
\end{tabular}

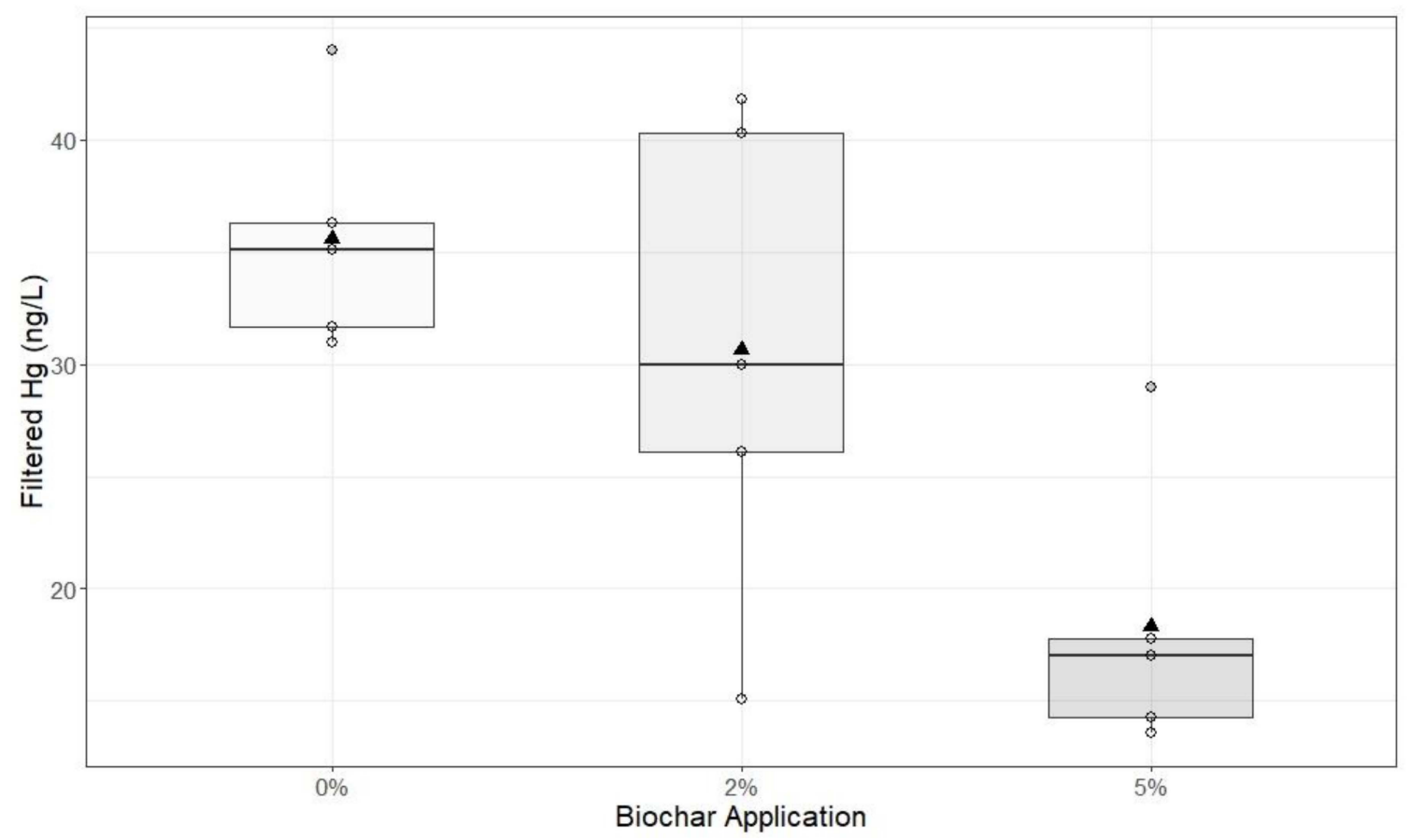

Figure 7. Filtered mercury in Experiment 3. Triangles indicate mean, bars show quartiles and standard deviation. The 5\% biochar significantly decreased filtered $\mathrm{Hg}$ in the outflow immediately after leaching $(p=0.001, \mathrm{n}=5)$. 


\section{Discussion}

Without treatment, there is a long-term potential to have $\mathrm{Hg}$ released into the environment, either through storm water drainage or in eroding sediments at numerous mine sites throughout the Sierra Nevada. The biochar used in these studies was untreated and not aged and, therefore, provides a useful tool for both forest restoration and mine site remediation. One key finding of these laboratory experiments is that biochar can be effective for decreasing environmental risks from contaminants. This is similar to work with rice husk and corn stover biochars [22,23].

In all three laboratory experiments, the application of $5 \%$ biochar by weight was an effective remediation technique for $\mathrm{Hg}$-contaminated sediments and storm water. This application rate translates to approximately $2-10 \mathrm{Mg} / \mathrm{ha}$ applied to contaminated sites. One critical assumption is that the biochar or sediment would not be eroded and transported offsite. In environments where erosion and sediment transport into watersheds is a concern, using biochar is effective at $\mathrm{Hg}$ remediation [24].

When compared to using sulfur-treated rice husk biochar, the untreated woody feedstock biochar used in this study was also effective for removing $\mathrm{Hg}$, but levels of $\mathrm{Hg}$ contamination in our mine sediments and storm water were much less than laboratorycreated spike samples $(1000 \mathrm{mg} / \mathrm{kg}$ ) [22]. Further, our results are similar to the use of corn stover biochar to reduce movement of $\mathrm{Hg}$ from soil to spinach [22,23]. In contrast to these findings, work in flooded soils found that biochar had little impact on $\mathrm{Hg}$ immobilization, but these authors suggest that other biochars should be tested under redox conditions found in flooded soils [25]. In addition, untreated and sulfurized wood-based biochar was used to treat wastewater, and sulfurized biochar was more effective at removing $\mathrm{Hg}$ from aqueous solutions [26]. However, usually only manure- and biosolid-derived biochars are high in sulfur as compared to wood-based biochar. These are also not produced within forested landscapes. However, it is clear from these various studies that $\mathrm{Hg}$ contamination can be remediated with biochar.

In our study, additions of biochar to storm water runoff and mine sediment columns decreased turbidity and $\mathrm{Hg}$ concentrations, except when saturated conditions resulted in increased sediment transport within the mesocosms. Valve placement in mesocosm studies could contribute to increased sediment transportation. Locating the valve vertically beneath mesocosm trays with narrow mesh overlay may improve experimental design. Column experiments containing hydraulic mine debris treated with $5 \%$ biochar produced a significant reduction in $\mathrm{FHg}$ in the outflow compared to control columns. The effectiveness of biochar on FHg concentrations over the course of this study is likely due to inherent biochar chemical structures responsible for its sorption abilities, rather than physical retention [15]. Furthermore, the ability of biochar to sorb $\mathrm{Hg}$ also implies a decrease in methylation potential, which is critical for increasing food security [27].

Currently, there are few in-woods options for creating the large quantities of biochar needed for remediation of mine sites, but technologies are evolving. The potential to create biochar on-site makes the use of woody biomass as the feedstock for biochar feasible, and takes advantage of abundant low-cost, low-quality woody residues that are local to contaminated sites [13]. Using local wood supplies has an added benefit of adding value to nonmerchantable residues, which can reduce wildfire risk. It is often the case that low-value woody residues created from thinning operations or brush disposal are burned in slash piles. However, in-woods processing can be used to create biochar within a short distance from mine sites [28]. This is particularly true in the Sierra Nevada Mountains, where overstocked stands may lead to an increased risk of wildfire, particularly during summer drought periods. There are thousands of abandoned $\mathrm{Hg}$-contaminated mine sites across California and the western US, where biochar could be used to restore soil processes, reduce wind and water erosion, provide wildlife forage, remove contaminants, and increase site productivity [13]. It is critical to understand the physical and chemical properties of biochar before application, since they vary depending on pyrolysis temperature and feedstock type [15-17]. In Columbia, the use of biochar on $\mathrm{Hg}$-contaminated mine tailings 
reduced bioavailability and transformed $\mathrm{Hg}$ species into less toxic, soluble, reactive, and bioavailable forms [29]. In the northeastern USA, biochar has also been added to capping materials or mixed directly into the sediments to further enhance its applicability for $\mathrm{Hg}$ remediation $[8,24,26]$. Reduction in $\mathrm{Hg}$ transport from contaminated sediments during storm events can decrease bioavailable $\mathrm{Hg}$ concentrations and, therefore, biochar may help vegetation become established to provide soil cover and reduce erosion [30]. Ultimately, the goal of using biochar, particularly biochar made from local woody residues, is to reduce $\mathrm{Hg}$ in storm water and sediments and to reduce $\mathrm{MeHg}$ concentrations in biota [8,30].

Biochar created from local feedstocks and applied to contaminated hydraulic mine debris can reduce the transport of $\mathrm{Hg}$ from contaminated sites, depending on the method of application. The best application method is likely one that retains biochar and sorbed silts and clays on site, such as a mat, waddle, or other passive filtration system. Decreases in $\mathrm{THg}$ and FHg transported from hydraulic mine debris may decrease the amounts of $\mathrm{Hg}$ available for methylation by benthic microbial communities in downstream environments [6-8].

\section{Conclusions}

Woody-feedstock-derived biochars may provide a local and effective solution to remediate historic hydraulic gold mine sites. These three laboratory experiments demonstrate the potential of using woody residues to create biochar and reduce $\mathrm{Hg}$ contamination, but additional field testing is needed to determine the rates and methods of application. Considering the number of hectares that are impacted in California alone, using a locally sourced biochar to filter $\mathrm{Hg}$ from storm water or reduce leaching or runoff means that Hg exposure decreases. Biochar type will play an important role in how much and which $\mathrm{Hg}$ species is absorbed. However, knowing that untreated woody biomass biochar is an effective remediation treatment for historic hydraulic mining operations that left $\mathrm{Hg}$ in the soil is important for expanding this work with field trials.

We provide laboratory data that show the value of using low-value woody residues to create a high-value product that can reduce $\mathrm{Hg}$ contamination in storm water and soil particles. With newer in-woods processing methods for creating biochar, the use of local feedstock to solve local problems is promising. However, this work should be replicated in field trials to determine the best locations to capture $\mathrm{Hg}$ and the best biochar processing methods. Using these techniques, forest managers can simultaneously reduce a wildfire risk and benefit mine site restoration. Furthermore, future long-term research should examine ecological, hydrological, and soil-specific responses.

Author Contributions: Conceptualization, M.B. and C.M.; methodology, M.B.; validation, M.B., C.M., and J.W.; formal analysis, M.B., C.M., and J.W.; investigation, M.B., C.M., and J.W.; resources, M.B. and C.M.; data curation, M.B. and C.M.; writing-original draft preparation, M.B., C.M., and J.W.; writing-review and editing, M.B., D.S.P.-D., C.M., and J.W.; visualization, M.B. supervision, C.M. and J.W.; project administration D.S.P.-D., C.M., and J.W.; funding acquisition, C.M. All authors have read and agreed to the published version of the manuscript.

Funding: This research was funded by The Bella Vista Foundation.

Data Availability Statement: The data presented in this study are available in this article "Biochar as a Soil Amendment: Reduction of Mercury Transport from Hydraulic Mine Debris".

Acknowledgments: We would like to thank all of the staff at The Sierra Fund for contributing their time and efforts to source materials and grant funding for this project. To Dave Brown for his contributions to the investigation, writing, and review of this material. Also, to thank Robin Donatello for her statistical advice and recommendations.

Conflicts of Interest: The authors declare no conflict of interest. The funders had no role in the design of the study; in the collection, analyses, or interpretation of data; in the writing of the manuscript, or in the decision to publish the results. 


\section{References}

1. Alpers, C.N.; Hunerlach, M.P.; May, J.T.; Hothem, R.L. Mercury Contamination from Historical Gold Mining in California; USGS: Reston, VA, USA, 2000. [CrossRef]

2. James, L.A. Sediment from hydraulic mining detained by Englebright and small dams in the Yuba basin. Geomorphology 2005, 71, 202-226. [CrossRef]

3. Fleck, J.A.; Alpers, C.N.; Marvin-Dipasquale, M.; Kakouros, E.; Kieu, L.H.; Agee, J.L. The Effects of Sediment and Mercury Mobilization in the South Yuba River and Humbug Creek Confluence Area, Nevada County, California: Concentrations, Speciation and Environmental Fate-Part 2: Laboratory Experiments; USGS: Reston, VA, USA, 2011. [CrossRef]

4. Monohan, C. Humbug Creek Watershed Assessment Report; The Sierra Fund: Nevada City, CA, USA, 2015; Available online: https:/ / www.sierrafund.org/humbug-creek-report-2015/ (accessed on 17 December 2018).

5. $\quad$ Singer, M.; Aalto, R.; James, L.A.; Kilham, N.; Higson, J.; Ghoshal, S. Enduring Legacy of a Toxic Fan via Episodic Redistribution of California Gold Mining Debris; National Academy of Sciences of the United States of America: Washington, DC, USA, 2013; Volume 110, pp. 18436-18441. [CrossRef]

6. Domagalski, J. Mercury and methylmercury in water and sediment of the Sacramento River Basin, California. Appl. Geochem. 2001, 16, 1677-1691. [CrossRef]

7. DiPasquale, M.M.; Lutz, M.A.; Brigham, M.E.; Krabbenhoft, D.P.; Aiken, G.R.; Orem, W.H.; Hall, B.D. Mercury cycling in stream ecosystems. 2. Benthic methylmercury production and bed sediment-pore water partitioning. Environ. Sci. Technol. 2009, 43, 2726-2732. [CrossRef] [PubMed]

8. Gilmour, C.C.; Riedel, G.S.; Riedel, G.; Kwon, S.; Landis, R.; Brown, S.S.; Ghosh, U. Activated Carbon Mitigates Mercury and Methylmercury Bioavailability in Contaminated Sediments. Environ. Sci. Tech. 2013, 47, 13001-13010. [CrossRef] [PubMed]

9. Ouédraogo, O.; Chételat, J.; Amyot, M. Bioaccumulation and Trophic Transfer of Mercury and Selenium in African Sub-Tropical Fluvial Reservoirs Food Webs (Burkina Faso). PLoS ONE 2015, 10, e0123048. [CrossRef] [PubMed]

10. Fleming, E.; Mack, E.; Green, P.; Nelson, D. Mercury Methylation from Unexpected Sources: Molybdate-Inhibited Freshwater Sediments and an Iron-Reducing Bacterium. Appl. Environ. Microbiol. 2006, 72, 457-464. [CrossRef] [PubMed]

11. National Research Council (US) Committee on the Toxicological Effects of Methylmercury. Toxicological effects of methylmercury. In Chemistry, Exposure, Toxicokinetics, and Toxicodyanmics; National Academies Press: Washington, DC, USA, 2000 ; Volume 2.

12. Bussan, D.D.; Sessums, R.F.; Cizdziel, J.V. Activated Carbon and Biochar Reduce Mercury Methylation Potentials in Aquatic Sediments. Bull. Environ. Contam. Tox. 2016, 96, 536-539. [CrossRef]

13. Rodriguez-Franco, C.; Page-Dumroese, D.S. Woody biochar potential for abandoned mine land restoration in the U.S.: A review. Biochar 2021, 3, 7-22. [CrossRef]

14. Beesley, L.; Moreno-Jiménez, E.; Gomez-Eyles, J.L.; Harris, E.; Robinson, B.; Sizmur, T. A review of biochars' potential role in the remediation, revegetation and restoration of contaminated soils. Environ. Pollut. 2011, 159, 3269-3282. [CrossRef]

15. Harvey, O.R.; Herbert, B.E.; Rhue, R.D.; Kuo, L. Metal interactions at the biochar-water interface: Energetics and structure-sorption relationships elucidated by flow adsorption microcalorimetry. Environ. Sci. Tech. 2011, 45, 5550-5556. [CrossRef]

16. Li, H.; Dong, X.; Silva, E.B.; Oliveira, L.M.; Chen, Y.; Ma, L.Q. Mechanisms of metal sorption by biochars: Biochar characteristics and modifications. Chemosphere 2017, 178, 466-478. [CrossRef]

17. Keiluweit, M.; Nico, P.S.; Johnson, M.G.; Kleber, M. Dynamic Molecular Structure of Plant Biomass-Derived Black Carbon (Biochar). Environ. Sci. Tech. 2010, 44, 1247-1253. [CrossRef]

18. Gomez-Eyles, J.; Yupanqui, C.; Beckingham, B.; Riedel, G.; Gilmour, C.; Ghosh, U. Evaluation of Biochars and Activated Carbons for In Situ Remediation Of Sediments Impacted With Organics, Mercury, And Methylmercury. Environ. Sci. Tech. 2013, 47, 13721-13729. [CrossRef]

19. California Department of Parks and Recreation (DPR). Malakoff Diggins State Historic Park. 2010. Available online: http: // www.parks.ca.gov / pages / 494 / files /MalakoffDigginsWebBrochure2010.pdf (accessed on 28 October 2019).

20. Curtis, J.A. Geomorphic Map of Malakoff Diggins State Historic Park, California; USGS Data Release; USGS: Reston, VA, USA, 2017. [CrossRef]

21. Holdrege \& Kull. Report of Soil and Groundwater Investigation at the Blue Point Mine Property; Holdrege \& Kull: Nevada City, CA, USA, 2003.

22. O'Connor, D.; Peng, T.; Li, G.; Wang, S.; Duan, L.; Mulder, J.; Cornelissen, G.; Cheng, Z.; Yang, S.; Hou, D. Sulfur-modified rice husk biochar: A green method for the remediation of mercury contaminated soil. Sci. Total Environ. 2018, 621, 819-826. [CrossRef]

23. Zhao, W.; Cui, Y.; Sun, X.; Wang, H.; Teng, X. Corn stover biochar increased edible safety of spinach by reducing the migration of mercury from soil to spinach. Sci. Total Environ. 2021, 758, 143883. [CrossRef]

24. Wang, A.O.; Ptacek, C.J.; Blowes, D.W.; Gibson, B.D.; Landis, R.C.; Dyer, J.A.; Ma, J. Application of hardwood biochar as a reactive capping mat to stabilize mercury derived from contaminated floodplain soil and riverbank sediments. Sci. Total Environ. 2019, 652, 549-561. [CrossRef] [PubMed]

25. Beckers, F.; Mahmoud Awad, Y.; Beiyuan, J.; Abrigata, J.; Mothes, S.; Tsang, D.; Sik Ok, Y.; Rinklebe, J. Impact of biochar on mobilization, methylation, and ethylation of mercury under dynamic redox conditions in a contaminated floodplain soil. Environ. Int. 2019, 127, 276-290. [CrossRef]

26. Park, J.H.; Wang, J.J.; Zhou, B.; Mikhael, J.E.R.; DeLaune, R.D. Removing mercury from aqueous solution using sulfurized biochar and associated mechanisms. Environ. Pollut. 2019, 244, 627-635. [CrossRef] [PubMed] 
27. Bloom, N.S.; Preus, E.; Katon, J.; Hiltner, M. Selective extractions to assess the biogeochemically relevant fractionation of inorganic mercury in sediments and soils. Anal. Chim. Acta 2003, 479, 233-248. [CrossRef]

28. Page-Dumroese, D.; Busse, M.; Archuleta, J.; McAvoy, D.; Roussel, E. Methods to Reduce Forest Residue Volume after Timber Harvesting and Produce Black Carbon. Scientifica 2017, 2017, 2745764. [CrossRef]

29. Gamboa-Herrera, J.A.; Ríos-Reyes, C.A.; Vargas-Fiallo, L.Y. Mercury speciation in mine tailings amended with biochar: Effects on mercury bioavailability, methylation potential and mobility. Sci. Total Environ. 2021, 760, 143959. [CrossRef] [PubMed]

30. Eckley, C.S.; Gilmour, C.C.; Janssen, S.; Luxton, T.P.; Randall, P.M.; Whalin, L.; Austin, C. The assessment and remediation of mercury contaminated sites: A review of current approaches. Sci. Total Environ. 2020, 707, 136031. [CrossRef] [PubMed] 